Elżbieta Gajewska

Uniwersytet Pedagogiczny, Kraków

Magdalena Sowa

Katolicki Uniwersytet Lubelski Jana Pawła II

\title{
REFLEKSYJNA PRAKTYKA W NAUCZANIU JĘZYKA SPECJALISTYCZNEGO
}

\section{Reflective practice in teaching Language for Specific Purposes (LSP)}

Compared to colleagues teaching foreign languages for general purposes, who can use ready-made syllabuses or programs, the LSP teacher has to reflect on methodology at the level of course planning. The scope and nature of the proposed course content is tailored to the specific needs of a student. The analysis of these needs is based on interviews and questionnaires. There are many examples of such tools, but none of them are universal or exhaustive, nor can they be. The purpose of this article is to propose a set of parameters to facilitate investigation of the educational context, which could be a starting point for the development of questionnaires tailored to specific education needs.

Keywords: language for specific purposes, syllabus, language needs, needs analysis, needs analysis tools

Słowa kluczowe: język specjalistyczny, program nauczania, potrzeby językowe, analiza potrzeb, narzędzia identyfikacji potrzeb

\section{Wstęp}

Praktyka nauczania pokazuje, że nauczyciel języka specjalistycznego (JS) częściej niż jego koledzy uczący języka obcego (JO) pod kątem ogólnym wykazuje refleksyjną postawę w wykonywaniu swojego zawodu. W przypadku istnienia gotowego programu nauczania oraz pomagających $w$ jego realizacji materia- 
łów (podręczników, dodatkowych ćwiczeń itp.) nauczyciel może po prostu realizować ten program. Kiedy takich pomocy brak, nauczyciel sam musi podejmować istotne decyzje w zakresie kształtu kursu, jego celów i treści. Kontekst dydaktyczny wymusza zatem, aby stał się on nauczycielem refleksyjnym.

Samodzielne zidentyfikowanie potrzeb edukacyjnych uczących się oraz opracowanie operacyjnych działań i materiałów nauczania, adekwatnych do określonych uprzednio potrzeb, nie jest rzeczą łatwą. Warto się zatem zastanowić, czy i w jaki sposób można przyjść z pomocą nauczycielowi JS, stającemu przed koniecznością przygotowania oferty nauczania dla grupy o profilu zawodowym. W niniejszym artykule podejmiemy próbę ułatwienia pracy tej grupie nauczycieli, skupiając się zasadniczo na wstępnej fazie opracowania kursu dla potrzeb zawodowych, tj. na analizie potrzeb. W pierwszej kolejności przyjrzymy się istniejącym narzędziom w zakresie identyfikacji potrzeb, opracowanym przez różnych autorów. Następnie, zastanowimy się, czy i na ile te gotowe narzędzia są uniwersalne i wyczerpujące dla wszelkich specjalistycznych kontekstów edukacyjnych, aby wreszcie, w ostatniej części, zaproponować własne udoskonalenia w tym zakresie.

\section{Programowanie kursu JS}

Planowanie kursu JS zaczyna się każdorazowo od stworzenia obrazu odbiorcy kształcenia oraz jego potrzeb komunikacyjnych w poznawanym języku. W przypadku JS można wyodrębnić dwa typy sytuacji, w których uczący się rozpoczyna naukę JO: uczenie się dla celów zawodowych oraz uczenie się dla potrzeb zawodowych (Gajewska i Sowa, 2014). W pierwszym przypadku chodzi o naukę języków zawodowych lub branżowych do wykorzystania ich w późniejszej karierze, zaś kursy tego typu adresowane są do szerzej profilowanych grup docelowych. W drugim przypadku nauka dokonuje się pod kątem potrzeb konkretnej grupy odbiorców (a nawet pojedynczego odbiorcy) i mamy do czynienia z typowymi kursami „szytymi na miarę”. Klasyczne kursy dla pojedynczego odbiorcy są typowe dla glottodydaktyki specjalistycznej, nie są bynajmniej jedyną formą kształcenia językowego do celów zawodowych.

Niektóre z czynników wpływających na profil kursu JS są na tyle typowe, że pozwalają tworzyć ofertę adresowaną do szerszego kręgu zainteresowanych. Zaliczyć do nich można m.in. dziedzinę, do której odnosi się dany dyskurs specjalistyczny, kontekst korzystania z danego języka (specjalistycznego lub ogólnego), stopień profesjonalizacji odbiorców kształcenia oraz sposób poświadczenia zdobytych umiejętności.

Powyższą listę można byłoby uzupełnić jeszcze o kilka aspektów - takich jak czas trwania kursu, dobrowolność lub przymusowość podjętego 
kształcenia bądź też (nie)jednorodność grupy - choć zawierają się one pośrednio w omówionych kryteriach. Wymienione parametry krzyżują się ze sobą, w mniejszy lub większy sposób definiując ostateczny profil zaproponowanego kształcenia. Kompleksowość czynników wpływających na planowanie kursu JS obrazuje poniższy schemat.

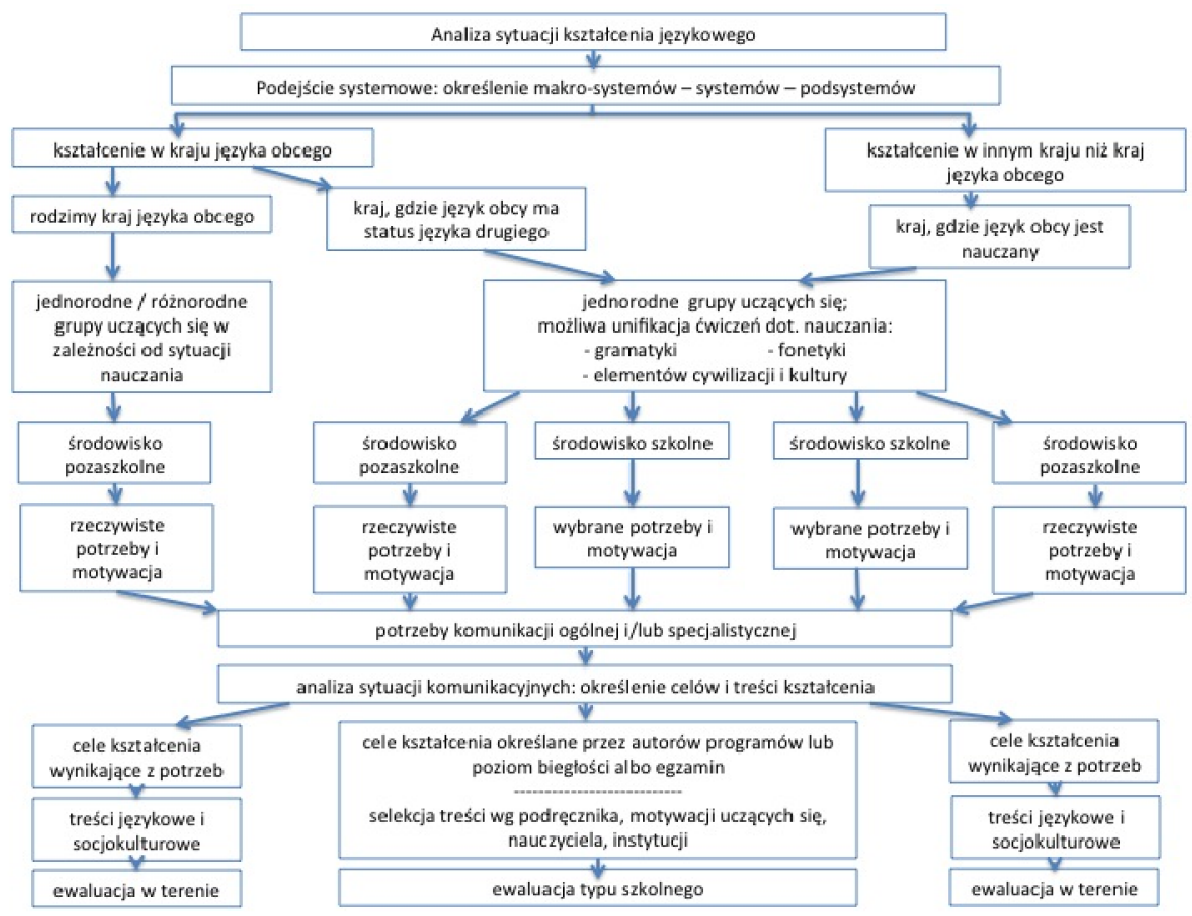

Schemat 1: Opis planowania kursu językowego dla odbiorców o specyficznych potrzebach komunikacyjnych (wg Eurin Balmet i Henao de Legge, 1992: 76).

Chcąc znaleźć odbiorców dla projektowanego przez siebie szkolenia, nauczyciel zatrudniony w komercyjnej szkole językowej będzie musiał dokonać innych wyborów niż lektor kształcący studentów politechniki lub nauczyciel w szkole profilowanej zawodowo. Oznacza to, że nauczanie JS nie zawsze obowiązkowo musi rozpoczynać się od szczegółowej analizy potrzeb. Pewne parametry pomagają scharakteryzować większe kręgi uczących się, określając zarazem specyficzne aspekty ich kształcenia. Kombinacja wielu ogólnych czynników daje w rezultacie opis zawężonego, ale ciągle dość szerokiego grona adresatów, pozwalając przygotować dla nich odpowiednio sprofilowany kurs. Przynależność do takiej czy innej grupy nie tylko determinuje potrzeby językowe, ale także rzutuje na sposób ich zaspokajania, czyli decyduje o formach 
podejmowanej nauki. Warto zatem dokonać przeglądu narzędzi stosowanych do określania profilu grupy specjalistycznej w celu dopasowania odpowiedniego programu specjalistycznego kształcenia językowego.

\section{Narzędzia pomagające w określeniu profilu grupy specjalistycznej}

Jednym z instrumentów, jakim można posłużyć się do określenia profilu odbiorców kształcenia jest analiza systemiczna. Polega ona na spisaniu wszystkich parametrów odnoszących się do określonej sytuacji edukacyjnej, które mogą odegrać rolę w programowaniu kursu. Lista czternastu takich parametrów została opracowana przez Eurin Balmet i Henao de Legge (1992: 11). Zdefiniowanie treści kształcenia powinno być poprzedzone rozpatrzeniem i uwzględnieniem takich elementów, jak zapotrzebowanie instytucjonalne i społeczne uczących się, społeczno-kulturowy profil uczących się i nauczyciela, językowe oraz pozajęzykowe potrzeby uczących się, sytuacje komunikacyjne do opanowania w języku docelowym, dziedziny naukowe, zasoby i ograniczenia finansowe, czasowe, ludzkie, otoczenie edukacyjne i społeczno-kulturowe.

Refleksja nad motywami powstawania kursu dowodzi, że niezwykle istotna w jego opracowaniu jest osoba uczącego się (rzeczywistego odbiorcy kursu), który jednak z reguły nie jest zleceniodawcą. Przed określeniem szczegółowego programu kształcenia warto zastanowić się, do kogo kierowana jest oferta edukacyjna w zakresie JS. W celu określenia profilu odbiorców można posłużyć się gotowymi zestawami pytań, których dużą ilość dostarcza literatura przedmiotu (dla języka francuskiego m.in. Carras et al., 2007: 25-26; Lehmann, 1993: 47-48). Korzystanie z nich wymaga jednak krytycznej oceny.

Analiza profilu uczących się w ścisłym tego słowa znaczeniu odbywa się zasadniczo w oparciu o dwa główne parametry. Po pierwsze, bierze pod uwagę poziom znajomości języka obcego, najczęściej badany skalą biegłości proponowaną przez ESOKJ. Na ogół towarzyszą mu pytania o przeszłość edukacyjną uczących się. Po drugie, uwzględnia stopień profesjonalizacji uczących się, który pozwala ocenić poziom umiejętności zawodowych i odróżnia początkujących w zawodzie od doświadczonych specjalistów.

\section{Narzędzia przydatne w identyfikacji specjalistycznych potrzeb językowych}

Poza określeniem profilu odbiorcy kształcenia, nauczyciel JS powinien zidentyfikować potrzeby językowe docelowych odbiorców kursu, którzy posługiwać się będą językiem na różne sposoby, w różnych okolicznościach i w różnych sytuacjach komunikacyjnych (cf. Delhaye, 2006). Przydatna mu w tym 
będzie analiza potrzeb, którą traktuje się jako główną pomoc przy określaniu programu kursu dla potrzeb zawodowych.

Analiza potrzeb polega na dokładnym zakreśleniu sytuacji komunikacyjnych, w których uczący się będzie posługiwał się językiem obcym w swojej działalności zawodowej, jak również na określeniu wiedzy i umiejętności językowych oraz zawodowych, które będzie musiał zdobyć w ciągu zaplanowanego kształcenia (Mangiante i Parpette, 2004). Biorąc pod uwagę, że kurs powstaje na zamówienie i odpowiada pilnej potrzebie uczącego się, nie może być mowy o zajmowaniu się szeroką gamą tematów, różnicowaniem kompetencji i sprawności, lecz należy skupić się wyłącznie na tych zagadnieniach i umiejętnościach, które w pierwszej kolejności będą przydatne uczącemu się w jego życiu zawodowym. Oznacza to znalezienie odpowiedzi na szereg pytań typu: Gdzie i w jakich sytuacjach uczq̨cy się będzie posługiwał się językiem obcym w sferze zawodowej? Z kim będzie miał do czynienia? $O$ czym będzie mówit/pisał? W jaki sposób będzie się komunikowat? Czy i co będzie czytał/pisał? Jakie zadania w języku obcym będzie musiał wykonywać? itp.

W pewnych sytuacjach nauczyciel będzie sam mógł udzielić odpowiedzi na te pytania, opierając się na własnym doświadczeniu lub doświadczeniu grup, z którymi wcześniej zdarzyło mu się pracować. Czasami jednak, gdy zlecenia dotyczą obszarów mało znanych bądź zupełnie mu nieznanych, konieczny będzie kontakt ze środowiskiem zawodowym, czyli z samymi uczącymi się lub ze zleceniodawcą. Szczegółowy wywiad lub ankieta pomoże nauczycielowi JS określić m.in. ogólny kontekst komunikacji (środowisko, sektor, branża, rodzaj stanowiska itp.), rolę i rangę komunikacji oraz parametry interakcji (stosunki symetryczne i/lub asymetryczne), rodzaje kontaktów (twarzą w twarz, przed dużą publicznością, przewodniczenie zebraniom, udział w konferencjach itp.), rodzaje użytych środków komunikacji (rozmowa twarzą w twarz, przez telefon, na piśmie, przez internet itp.), rodzaj wariantu języka dominującego w komunikacji (potoczny, staranny, akademicki, regionalny itp.) czy wreszcie rodzaj kodu języka (mowa czy pismo).

Określenie językowych potrzeb uczących się będzie dużo prostsze w chwili opracowywania kursu na konkretne zlecenie niż w ramach zinstytucjonalizowanej oferty kształcenia. W tym drugim przypadku, nie mogąc precyzyjnie określić sytuacji komunikacyjnych, nauczyciel bardziej skupi się na doborze tematów właściwych danej dyscyplinie i zróżnicuje zakres zagadnień, wzbogacając tym samym program kursu.

Mówiąc o analizie potrzeb, należy pamiętać, że nie może być ona dokonana przez nauczyciela raz na zawsze. Według Mangiante i Parpette (2004: 24) istnieją przynajmniej dwa powody, dla których powinna być ona traktowana w sposób rozwojowy i ewolucyjny. Pierwszy dotyczy czasu trwa- 
nia kursu, który przeważnie jest bardzo krótki w stosunku do zidentyfikowanych potrzeb. Ograniczony czas zmusza nauczyciela do nieustannego korygowania wyborów odnośnie tego, co powinno pojawić się w trakcie szkolenia. Wybory te mogą być zarazem kwestionowane przez uczących się, którzy będą mieć inny pogląd na tę kwestię i będą woleli pracować nad czymś innym. Dodatkowo, niektóre omawiane zagadnienia mogą być przyczyną pojawienia się nowych potrzeb czy oczekiwań ze strony uczących się.

Druga przyczyna jest natury technicznej. Ponieważ kurs JS jest przygotowywany przez instytucję kształcącą, rzadkie są przypadki, kiedy nauczyciel spotyka i poznaje swoich uczniów przed rozpoczęciem kursu. Program tego ostatniego zostanie przygotowany głównie w oparciu o mniej lub bardziej trafne założenia, a uczniowie będą mogli wypowiedzieć się na jego temat dopiero po pierwszych zajęciach. Może się więc zdarzyć, że oczekiwania odbiorców nie będą w pełni odpowiadały założeniom autora kursu, a to wymagać będzie reorganizacji pewnych założeń kształcenia.

Można wreszcie wyobrazić sobie sytuację, kiedy w ramach jednorodnej na pierwszy rzut oka grupy będą uwidaczniały się różne potrzeby poszczególnych jej członków. Wśród uczęszczających na ten sam kurs inżynierów mechaników mogą pojawić się tacy, którzy będą chcieli opanować język w celu czytania literatury fachowej; tacy, których interesować będzie czynny udział w międzynarodowym projekcie mającym na celu budowę instalacji termicznego przekształcania odpadów komunalnych, lub wreszcie tacy, których celem będzie zatrudnienie się w muzeum techniki i opowiadanie zwiedzającym o wynalazkach inżynieryjnych. Nauczyciel JS będzie tu mieć do czynienia z osobami o identycznym profilu, reprezentujących tę samą dyscyplinę, jednak każda z nich będzie chciała opanować odmienne kompetencje docelowe. Potrzeby pierwszej grupy odbiorców dotyczyć będą rozwijania kompetencji czytania pism specjalistycznych, z pominięciem sprawności mówienia czy pisania. W drugim przypadku akcent zostanie położony na interakcję słowną (rozumienie i wykonywanie poleceń, formułowanie pytań, wymiana poglądów, koleżeńskie stosunki w pracy). Praca w muzeum techniki wymaga natomiast umiejętności jasnej prezentacji i opisu, a więc kompetencji związanych z wypowiedzią ustną, co dodatkowo może być poszerzone o umiejętność zrozumiałego przekładu języka technicznego na język bardziej potoczny. Widać więc, że każdy z przedstawionych powyżej przypadków potrzebuje odmiennego scenariusza działań ze strony nauczyciela JS.

W celu zdobycia informacji na temat potrzeb odbiorców kursu nauczyciel może posłużyć się rozmaitymi narzędziami, takimi jak kwestionariusze, kontakty ze środowiskiem zawodowym (w tym obserwacje, nagrania, wywiady), podręczniki itp. 
Najprostszym sposobem określenia językowych potrzeb odbiorców kursu jest stworzenie listy pytań w formie kwestionariuszy lub ankiet (patrz np. formularz opracowany na potrzeby kursu języka hiszpańskiego prowadzonego w niemieckim przedsiębiorstwie branży elektronicznej; cf. Velásquez-Bellot, 2004; Mangiante, 2007: 139). Takie narzędzia są przydatne również w sytuacji bezpośredniego wywiadu z potencjalnym uczącym się. Pytania dotyczące kontekstu komunikacji, jej roli, natury kontaktów, środków komunikacji itp. można uzupełnić o kolejne, np. Czy uczq̨cy się będq posługiwali się językiem obcym $w$ kraju języka obcego czy $w$ ich rodzimym kraju? Jakie mogq być przewidywalne różnice kulturowe? itp.

Podstawową zaletą kwestionariuszy jest dostarczenie nauczycielowi informacji na temat edukacyjnej przeszłości uczących się, a także poznanie ich poglądów na własną kompetencję w języku obcym i oczekiwań wobec kursu.

\section{Kryteria pomagające w opracowaniu własnych narzędzi identyfikacji potrzeb}

Jak łatwo można zauważyć, wielorakość parametrów, które należy wziąć pod uwagę w ocenie potrzeb uczącego się, powoduje, że istniejące narzędzia będą różnić się od siebie, mniej lub bardziej uwypuklając takie czy inne elementy profilu. Ze względu na wieloaspektowy charakter analizy potrzeb nie jest możliwe stworzenie uniwersalnego formularza, uwzględniającego wszelkie potencjalne parametry tej analizy. W trakcie pozyskiwania danych na temat odbiorców kształcenia należy także mieć na uwadze, aby badania nie były uciążliwe dla ankietowanych. Dlatego kwestionariusz najczęściej uwzględnia jedynie aspekty najbardziej interesujące dla organizatorów kursu.

Biorąc pod uwagę powyższe stwierdzenia, celem niniejszego artykułu jest zaproponowanie listy parametrów użytecznych do stworzenia narzędzia odpowiedniego dla pojedynczych sytuacji kształcenia, które mogłoby zastąpić miejsce uniwersalnej, ale bardzo obszernej ankiety. Jak już powiedziano wcześniej, istniejące narzędzia nie zawsze wyczerpująco uwzględniają wszystkie czynniki warunkujące profil kursu. W tym celu można zatem, na podstawie własnych kryteriów, opracować ankiety zawierające mniej lub bardziej rozbudowane kategorie tematyczne dostarczające potrzebnych informacji.

Przedstawiona niżej tabela zestawia najistotniejsze parametry, mające wpływ na ostateczny kształt kursu. Dotyczą one przede wszystkim: sytuacji edukacyjnej, ogólnej charakterystyki uczących się, potrzeb językowych, potrzeb dotyczących sposobu uczenia się, aspektów kulturowych oraz interkulturowych. 


\begin{tabular}{|c|c|}
\hline Aspekty organizacji kursu JS & Parametry kształcenia, na które mają wpływ \\
\hline \multicolumn{2}{|c|}{ Sytuacja edukacyjna } \\
\hline $\begin{array}{l}\text { Kontekst kształcenia: nauczanie JS do celów zawo- } \\
\text { dowych (nauczanie języków branżowych i zawo- } \\
\text { dowych) a nauczanie JS dla potrzeb zawodowych }\end{array}$ & $\begin{array}{l}\text { Mniej lub bardziej precyzyjne dopasowanie treści } \\
\text { do profilu odbiorców kształcenia (potrzeby i mo- } \\
\text { tywacje przewidywane lub rzeczywiste) }\end{array}$ \\
\hline Istniejące programy & Dobór celów i treści kształcenia \\
\hline Istniejące podręczniki (materiały) & Opracowanie materiałów oraz ćwiczeń \\
\hline $\begin{array}{l}\text { Środki techniczne dostępne w trakcie kursu } \\
\text { (w tym dostęp do internetu) }\end{array}$ & $\begin{array}{l}\text { Dobór metod oraz technik (praca w klasie, } \\
\text { e-learning) }\end{array}$ \\
\hline $\begin{array}{l}\text { Środki techniczne dostępne dla uczących się } \\
\text { (w tym dostęp do internetu) }\end{array}$ & $\begin{array}{l}\text { Dobór metod oraz technik (praca własna, } \\
\text { e-learning) }\end{array}$ \\
\hline \multicolumn{2}{|c|}{ Ogólna charakterystyka uczących się } \\
\hline Liczebność grupy & Dobór metod oraz technik \\
\hline Kontakt ze środowiskiem zawodowym & $\begin{array}{l}\text { Dostęp do materiałów autentycznych, możliwość } \\
\text { prowadzenia ćwiczeń oraz dokonywania ewaluacji } \\
\text { w terenie }\end{array}$ \\
\hline Wiek i płeć uczącego się & $\begin{array}{l}\text { Style zachowań oraz interakcji (nauczyciel-uczeń, } \\
\text { uczeń-uczeń) }\end{array}$ \\
\hline Stanowisko w firmie & Style zachowań oraz interakcji \\
\hline Wykształcenie i doświadczenie zawodowe & $\begin{array}{l}\text { Stopień profesjonalizacji (możliwość odwołania się do } \\
\text { wiedzy zawodowej posiadanej przez uczących się) }\end{array}$ \\
\hline $\begin{array}{l}\text { Biegłość w zakresie danego języka obcego (bazo- } \\
\text { wego dla poznawanego JS) }\end{array}$ & $\begin{array}{l}\text { Indywidualizacja nauczania (konieczność przygo- } \\
\text { towania dodatkowych ćwiczeń) }\end{array}$ \\
\hline Znajomość innych języków obcych & Transfer pozytywny i negatywny \\
\hline Biegłość w zakresie języka ojczystego & $\begin{array}{l}\text { Ewentualna konieczność działań naprawczych } \\
\text { w obrębie stwierdzonych deficytów }\end{array}$ \\
\hline $\begin{array}{l}\text { Dyspozycyjność oraz stopień obciążenia obowiąz- } \\
\text { kami (zawodowymi, rodzinnymi itd.) }\end{array}$ & $\begin{array}{l}\text { Forma kształcenia (konieczność wprowadzania } \\
\text { elementów nauczania zdalnego i pracy autono- } \\
\text { micznej); tempo kształcenia (częstotliwość zajęć, } \\
\text { realistyczne oczekiwania wobec uczących się) }\end{array}$ \\
\hline Kształcenie podjęte dobrowolnie lub przymusowo & $\begin{array}{l}\text { Konieczność budzenia lub wzmacniania motywacji } \\
\text { w trakcie kształcenia }\end{array}$ \\
\hline $\begin{array}{l}\text { Sposób i zakres wspierania kształcenia przez } \\
\text { instytucję zamawiającą kurs }\end{array}$ & $\begin{array}{l}\text { Formy kształcenia; mniejsza lub większa koniecz- } \\
\text { ność wzmacniania motywacji; oczekiwania wobec } \\
\text { uczących się }\end{array}$ \\
\hline \multicolumn{2}{|c|}{ Potrzeby dotyczące sposobu uczenia się } \\
\hline Modalność i inne cechy osobowościowe & $\begin{array}{l}\text { Dobór metod oraz technik odpowiadających } \\
\text { preferencjom uczących się }\end{array}$ \\
\hline Style i strategie dotyczące sposobu uczenia się & $\begin{array}{l}\text { Dobór metod oraz technik odpowiadających stylom } \\
\text { i strategiom oraz preferencjom uczących się }\end{array}$ \\
\hline $\begin{array}{l}\text { Wyobrażenia na temat siebie samego jako ucznia } \\
\text { (zdolny/niezdolny) i w konsekwencji stopnia } \\
\text { trudności podjętych zamierzeń }\end{array}$ & Ewentualna korekta postaw i wyobrażeń \\
\hline
\end{tabular}




\begin{tabular}{|c|c|}
\hline $\begin{array}{l}\text { Doświadczenia edukacyjne (w tym samokształce- } \\
\text { nie) }\end{array}$ & $\begin{array}{l}\text { Preferencje dotyczące sposobu uczenia się; moż- } \\
\text { liwość pracy autonomicznej lub semi- } \\
\text { autonomicznej }\end{array}$ \\
\hline $\begin{array}{l}\text { Sposób poświadczenia efektów kształcenia (ewa- } \\
\text { luacja w terenie, egzamin wewnętrzny, certyfika- } \\
\text { cja zewnętrzna) }\end{array}$ & Dobór celów, treści oraz technik kształcenia \\
\hline \multicolumn{2}{|c|}{ Potrzeby językowe } \\
\hline $\begin{array}{l}\text { Potrzeby deklarowane przez instytucję zamawia- } \\
\text { jącą }\end{array}$ & $\begin{array}{l}\text { Szeroki zakres parametrów warunkujących dobór } \\
\text { celów oraz treści kształcenia: wskazana weryfika- } \\
\text { cja w toku dalszej analizy potrzeb rzeczywistych }\end{array}$ \\
\hline $\begin{array}{l}\text { Potrzeby deklarowane przez podmiot kształcenia } \\
\text { (uczestników kursu) }\end{array}$ & $\begin{array}{l}\text { Wyodrębnienie oraz precyzyjne sformułowanie } \\
\text { tych potrzeb może niekiedy wymagać pomocy ze } \\
\text { strony organizatorów kursu (zasadnicze kryterium } \\
\text { warunkujące dobór celów oraz treści kształcenia) }\end{array}$ \\
\hline Dziedzina odniesienia & $\begin{array}{l}\text { Ogólny dobór celów i treści kształcenia (języko- } \\
\text { wych oraz zawodowych) }\end{array}$ \\
\hline $\begin{array}{l}\text { Sytuacje zawodowe, w których uczący się posłu- } \\
\text { guje się (lub będzie się posługiwał) JO }\end{array}$ & $\begin{array}{l}\text { Dobór celów i treści kształcenia (niezbędne umie- } \\
\text { jętności językowe i zawodowe: skrypty i scenariu- } \\
\text { sze komunikacyjne) }\end{array}$ \\
\hline $\begin{array}{l}\text { Zadania zawodowe wiążące się z daną profesją, } \\
\text { stanowiskiem lub miejscem pracy }\end{array}$ & $\begin{array}{l}\text { Dobór celów i treści kształcenia (niezbędne umie- } \\
\text { jętności językowe i zawodowe: scenariusze komu- } \\
\text { nikacyjne zgodne z daną logiką zawodową) }\end{array}$ \\
\hline $\begin{array}{l}\text { Tematyka kontaktów zawodowych z użytkowni- } \\
\text { kami JO }\end{array}$ & $\begin{array}{l}\text { Dobór celów i treści kształcenia (jednostki leksy- } \\
\text { kalne, morfologiczne i syntaktyczne); niezbędna } \\
\text { wiedza zawodowa }\end{array}$ \\
\hline Funkcje językowe & Dobór celów i treści kształcenia \\
\hline Sprawności zawodowe & Dobór celów i treści kształcenia \\
\hline Status rozmówców & Dobór celów i treści kształcenia \\
\hline Używane rejestry języka & Dobór celów i treści kształcenia \\
\hline $\begin{array}{l}\text { Kanał komunikacji (rozmowy twarzą w twarz, } \\
\text { zapośredniczone elektronicznie, korespondencja } \\
\text { tradycyjna) }\end{array}$ & $\begin{array}{l}\text { Typy dyskursu oraz preferowane gatunki; niekiedy } \\
\text { dobór treści (rozmowy de visu sprzyjające rozsze- } \\
\text { rzeniu tematyki komunikacji o kwestie nieformal- } \\
\text { ne-small talk); specyficzna wiedza zawodowa } \\
\text { (związana np. z umiejętnością skutecznego pro- } \\
\text { wadzenia negocjacji telefonicznych) }\end{array}$ \\
\hline $\begin{array}{l}\text { Miejsce wykorzystania zdobytej wiedzy i umiejętno- } \\
\text { ści (w kraju ojczystym lub kraju języka docelowego) }\end{array}$ & $\begin{array}{l}\text { Dobór celów i treści kształcenia (zakres uwzględnia- } \\
\text { nia treści ogólnych dotyczących życia codziennego) }\end{array}$ \\
\hline $\begin{array}{l}\text { Miejsce kształcenia (w kraju ojczystym lub kraju } \\
\text { języka docelowego) }\end{array}$ & $\begin{array}{l}\text { Dobór celów i treści kształcenia (zakres uwzględnia- } \\
\text { nia treści ogólnych dotyczących życia codziennego); } \\
\text { tempo kształcenia (ekspozycja na JO ułatwiająca } \\
\text { akwizycję); dostęp do danych autentycznych }\end{array}$ \\
\hline Potrzeby językowe związane z komunikacją w klasie & Dobór celów i treści kształcenia \\
\hline
\end{tabular}




\begin{tabular}{|l|l|}
\hline \multicolumn{2}{|c|}{ Aspekty kulturowe oraz interkulturowe } \\
\hline Znajomość kultury ogólnej i zawodowej & Dobór celów i treści kształcenia \\
\hline Pobyt w kraju docelowego JO & $\begin{array}{l}\text { Ewaluacja umiejętności językowych w terenie; } \\
\text { bezpośrednie doświadczenie kultury obcej }\end{array}$ \\
\hline Praca w kraju docelowego JO (JS) & $\begin{array}{l}\text { Ewaluacja zawodowych umiejętności językowych } \\
\text { w terenie; bezpośrednie doświadczenie obcej } \\
\text { kultury organizacyjnej i logiki zawodu/stanowiska }\end{array}$ \\
\hline $\begin{array}{l}\text { Kontakty zawodowe i/lub prywatne z rodzimymi } \\
\text { użytkownikami języka }\end{array}$ & $\begin{array}{l}\text { Zakres niezbędnej wiedzy socjokulturowej oraz } \\
\text { kompetencji socjolingwistycznej }\end{array}$ \\
\hline $\begin{array}{l}\text { Kontakty zawodowe i/lub prywatne z nierodzi- } \\
\text { mymi użytkownikami języka }\end{array}$ & $\begin{array}{l}\text { Kształtowanie wrażliwości i umiejętności interkul- } \\
\text { turowych }\end{array}$ \\
\hline Uwarunkowania kulturowe edukacji & $\begin{array}{l}\text { Style zachowań oraz interakcji (nauczyciel-uczeń, } \\
\text { uczeń-uczeń) }\end{array}$ \\
\hline
\end{tabular}

Tabela 1: Parametry przydatne w określaniu profilu kursu zawodowego (opracowanie własne).

Chociaż każdy ze wskazanych w tabeli parametrów rzutuje w pewien sposób na kształt i profil kursu, dopiero kombinacja kilku z nich precyzyjniej określa potrzeby kształcenia. Pracownik branży ubezpieczeniowej (dziedzina odniesienia) może mieć wpisane w zakres swoich obowiązków służbowych dokumentowanie szkody (zadania zawodowe) pocztą elektroniczną lub tradycyjną (cechy formalne dyskursów oraz gatunków), przy czym korespondencja w języku obcym obejmuje zasadniczo likwidowanie szkód powypadkowych (tematyka).

Niektóre z parametrów dostarczają zbliżonej wiedzy, różniąc się jednak perspektywą i zastosowanym aparatem pojęciowym (patrz np. sytuacje komunikacyjne oraz zadania zawodowe). Konstruując ankietę, organizator kursu może zatem wybrać parametry dostarczające przydatnych mu danych, zaś pominąć te, których nie będzie potrafił przełożyć na praktykę dydaktyczną.

Zaproponowane przez nas zestawienie aspektów kursu i/lub grupy docelowej oraz powiązanych z nimi parametrów kształcenia może być rozszerzane. Wybrane zagadnienia muszą zostać następnie przekształcone na operacyjne pytania. Inspirację w tym względzie mogą stanowić m.in. ankiety przedstawione w niniejszym artykule.

\section{Podsumowanie}

Jak wielokrotnie okazuje się w praktyce nauczania, nawet najlepiej pomyślane i doskonałe na pierwszy rzut oka narzędzia zawodzą lub mają swoje ograniczenia. Różnorodność odbiorców kształcenia oraz ich potrzeb nie pozwala nauczycielowi JS zadowalać się mniej lub bardziej uniwersalnymi i gotowymi rozwiązaniami, ale zmusza do poszukiwania sposobów działań adekwatnych do pojedynczych sytuacji i osób. W kontekście podjętego przez nas tematu łatwo wysnuć 
wniosek, że w skutecznym i pomyślnym wykonywaniu zawodu nauczyciela JS niezmiernie ważna jest umiejętność samodzielnego tworzenia operacyjnych narzędzi, dostosowanych do konkretnych odbiorców kształcenia oraz jednostkowych sytuacji edukacyjnych. Zaprojektowanie i wdrożenie w praktyce własnych rozwiązań nie jest możliwe bez dogłębnej analizy sytuacji edukacyjnej, dokonanej chociażby w oparciu o zaproponowane kryteria (patrz Tabela 1).

Należy jednak zauważyć, że informacje dostarczane przez poszczególne parametry nie dla każdego autora kursu będą miały takie samo znaczenie i będą w równym stopniu przydatne. Warto tutaj podkreślić, że refleksja na wstępnym etapie planowania kursu, tj. analizy potrzeb, odnosi się także do umiejętności oceny użyteczności i operatywności informacji pozyskiwanych na temat nauczanej grupy. Refleksyjny wywiad powinien odnosić się nie do wszystkich cech uczących się, lecz raczej tych z nich, które nauczyciel JS potrafi rzeczywiście uwzględnić w planowanym kształceniu: jeżeli nie będzie potrafił właściwie posłużyć się informacjami na temat preferowanych przez uczących się reprezentacji zmysłowych czy stylów nauki, lepiej, aby pominął pytania o te aspekty, a skupił się wyłącznie na tych, które potrafi w sposób operacyjny wykorzystać na potrzeby tworzonego przez siebie kursu JS.

\section{BIBLIOGRAFIA}

Carras, C., Tolas, J., Kohler, P., Szilagyi, E. 2007. Le Français sur objectifs spécifiques et la classe de langue. Paris: CLE International.

Delhaye, P. 2006. „De l'analyse de besoins à l'évaluation: le Diplôme de Compétence en Langue". Synergies Pays riverains de la Baltique 3: 127-140.

Gajewska, E., Sowa, M. 2014. LSP, FOS, Fachsprache... Glottodydaktyka języków specjalistycznych. Lublin: Werset.

Eurin Balmet, S., Henao de Legge, M. 1992. Pratiques du français scientifique. Paris: Hachette.

Lehmann, D. 1993. Objectifs spécifiques en langue étrangère. Les programmes en cours. Paris: Hachette.

Mangiante, J.-M. 2007. „Une démarche de référentialisation en français des professions: le partenariat université - Chambre de Commerce et d'Industrie de Paris (CCIP)". Le Français dans le monde. Recherches et applications 42: 129-144.

Mangiante, J.-M., Parpette, Ch. 2004. Le français sur Objectif Spécifique: de l'analyse des besoins à l'élaboration d'un cours. Paris: Hachette.

Velásquez-Bellot, A. 2004. „Metodología teórica del proceso de elaboración de un diseño curricular para la enseñanza de las lenguas con fines específicos". Revista Electrónica de Didáctica del Español como Lengua Extranjera. http:// www.educacion.gob.es/dctm/redele/Material-RedEle/Revista/200402/2004r edELE216Velazquez.pdf?documentld=0901e72b80e06a67 DW 21.10.2013. 